\title{
KONSEP DIRI PADA LANSIA DI PANTI WERDHA PANGESTI LAWANG
}

\author{
Santi Susilawati, Agus Setyo Utomo, Nurul Hidayah \\ Poltekkes Kemenkes Malang, Prodi Keperawatan Lawang, \\ E-mail: nh_150673@yahoo.com
}

\begin{abstract}
Abstrak
Konsep diri berkembang seiring dengan peningkatan usia seseorang. Konsep diri pada kelompok lansia dipengaruhi oleh faktor fisik, psikososial, spiritual dan ekonomi. Kebanyakan lansia dibawa keluarga ke panti dengan alasan tidak mampu mengurus lansia di rumah. Hal ini menjadikan lansia berpikir negatif tentang keputusan keluarga tersebut, sehingga mempengaruhi konsep diri. Dari fenomena tersebut, peneliti bertujuan untuk mengetahui gambaran konsep diri lansia di Panti Werdha Pangesti Lawang. Desain penelitian ini adalah diskriptif, dengan purposive sampling, sebesar 46 responden. Menggunakan alat ukur kuesioner. Hasil yang menunjukkan positif antara lain: 1) Gambaran diri lansia (63\%), 2) Ideal diri lansia (52,2\%), 3) Identitas diri lansia (58,7\%), 4) Konsep diri lansia yang tinggal di panti (63\%). Sedangkan yang menunjukkan hasil negatif adalah 1) Harga diri lansia $(56,5 \%)$, 2) Peran lansia $(69,6 \%)$. Salah satu factor terbesar yang menjadi penyebab adalah kurangnya dukungan/motivasi dari keluarga. Dari hasil penelitian ini, peneliti berharap perawat dapat memberikan pengertian pada keluarga untuk memberi motivasi pada lansia meski harus tetap dititipkan di panti, selain itu perawat juga melibatkan lansia dalam kegiatan-kegiatan bersama, antara lain: beribadah, senam lansia, menyiapkan makan bersama, bersih-bersih, serta memberikan penghargaan atas hasil kerja lansia seperti pujian sehingga lansia merasa dihargai dan berguna.
\end{abstract}

Kata Kunci: Lansia, Konsep Diri, Gambaran Diri, Ideal Diri, Harga Diri, Peran, Identitas Diri

\begin{abstract}
Self concept will grow with the increasing of age. Self concept in the elderly is more influenced by physical problems, psychosocial, spiritual and economic. Most of them being carry to nursing home by their families with a reason that they are not able to take care of their elderly at home. It its concequences a lot of elderly think negatively about the decision to put them at nursing home. Negative thinking makes them to have a negative self-concept. Purpose of this study is to know the self-concept of elderly in Nursing home Pangesti Lawang. This study used discriptive method with purposive sampling (46 respondents) and using questionnaires to collecting data. It is the negative result were 1) Self image (63\%), 2) Self Ideal (52,2\%), 3) Self identity (58,7\%), 6) Self-concept of elderly who lives in the nursing home (63\%). While the negative result showed: 1) Self esteem (56,5\%), 2) Role performance (69,6\%). Recommendation of this study to involve elderly in activities that they can do, can be prayer together, gymnastics, eat together, cleaning up, singing together and appreciation to the elderly is an important issue
\end{abstract}

Keywords: self-concept, self-image, self ideal, self-esteem, role performance, self identity, elderly

\section{PENDAHULUAN}

Konsep diri mengalami perubahan seiring dengan peningkatan usia (Baltes dalam Mass et al., 2011). Menurut WHO konsep diri pada lansia banyak dipengaruhi oleh masalah fisik, psikososial, spiritual dan ekonomi. Hasil studi penelitian lembaga demografi UI tahun 2005 menemukan bahwa $75 \%$ lansia menderita penyakit kronis, depresi dan gangguan konsep diri (Setyowati, 2013). Hasil penelitian Siregar (2013) mengenai perbedaan kualitas hidup antara lansia di Kecamatan Batang Angkola yang tinggal di rumah bersama keluarga dengan lansia yang tinggal di Panti Jompo Warga Mas Titian Ridho Ilahi menyatakan bahwa lansia yang tinggal di rumah secara 
kualitas psikologi dan sosial lebih baik dibandingkan lansia yang tinggal di panti.

Jumlah lansia di dunia telah mencapai lebih dari 629 juta jiwa dan diperkirakan akan mencapai lebih dari 1,2 milyar jiwa di tahun 2025 (Nugroho, 2008). Menurut hasil sensus penduduk tahun 2010, jumlah penduduk lansia di Indonesia mencapai 9,6\% dari jumlah penduduk Indonesia dan hampir 23\% lansia tinggal di institusi atau tempat pelayanan kesehatan.

Hasil studi pendahuluan yang dilakukan di Panti Werdha Pangesti Lawang tanggal 11 Januari 2016 diperoleh data jumlah lansia di panti ada 63 orang yang terdiri dari 24 laki-laki dan 39 perempuan. Menurut keterangan petugas panti, tidak semua lansia mau mengikuti kegiatan di panti dan ada beberapa yang memilih menyendiri. Hasil wawancara terhadap 5 lansia, 1 lansia mengatakan sedih tinggal di panti, dia ingin berkumpul dengan keluarganya namun keluarga tidak punya waktu, 2 lansia mengatakan kecewa dengan anak-anaknya yang menitipkan mereka di panti padahal mereka merasa masih sanggup mengurus dirinya sendiri, seorang lansia mengaku bosan dan bingung karena tidak ada pekerjaan yang bisa dikerjakan seperti di rumah, dan lansia yang lainnya mengatakan senang tinggal di panti karena dapat berinteraksi dengan lansia lain.

Bagi lansia yang berpikiran positif menganggap bahwa tinggal di panti werdha akan membuat dirinya memperoleh apa yang tidak dapat diberikan oleh anaknya misalnya kegiatan sosial dengan orang sebaya (Hutapea dalam Andini dan Supriyadi, 2013). Bagi lansia yang berpikiran negatif, tinggal di panti membuat dirinya merasa tidak berguna, merasa disingkirkan dan tidak dibutuhkan lagi sehingga akan memicu penurunan harga diri pada lansia tersebut (Azizah, 2011).

Tinggal di panti juga membuat hilangnya pekerjaan dan peran sosial yang biasa dilakukan oleh lansia di rumah. Hal ini akan membuat lansia tidak tahu perannya selama tinggal di panti. Kehilangan peran pada lansia menyebabkan ketidakpastian identitas lansia (Rini dalam Azizah, 2011). Penurunan konsep diri ke arah negatif akan berdampak pada kemunduran dalam berperilaku seperti mudah marah, sifat yang negatif, dan sifat seperti anak-anak (Hurlock, 2002). Lansia yang memiliki konsep diri negatif cenderung menarik diri dan jarang berinteraksi dengan lingkungan (Rahayu dalam Setyowati, 2005).

Oleh karena itu, kesehatan fisik dan mental lansia perlu mendapatkan perhatian khusus. Dengan memperhatikan aspek konsep diri diharapkan asuhan yang diberikan telah mencakup aspek psikososial sehingga asuhan keperawatan yang menyeluruh dapat diwujudkan (Kelliat, 1992). Selain itu lansia perlu mendapatkan dukungan sosial dari keluarga, teman dekat, orang-orang yang mempunyai ikatan emosi dengan lansia agar secara emosional lansia akan merasa lega karena diperhatikan, mendapat saran atau kesan yang menyenangkan pada dirinya (Azizah, 2011).

Berdasarkan fenomena di atas maka peneliti tertarik untuk meneliti tentang konsep 
diri lansia yang tinggal di panti werdha pangesti Lawang. Tujuan penelitian ini adalah untuk mengetahui konsep diri lansia di Panti Werdha Pangesti Lawang yang meliputi gambaran diri, ideal diri, harga diri, penampilan peran dan identitas diri.

\section{METODE PENELITIAN}

Metode penelitian ini adalah diskriptif dengan populasi 61 lansia. Teknik yang digunakan adalah purposive sampling dengan kriteria inklusi: lansia dengan usia $\geq 60$ tahun, bersedia menjadi responden, lansia yang mampu berkomunikasi secara verbal dan lansia yang kooperatif. Kriteria eksklusinya adalah lansia yang tidak hadir saat pengambilan data dilakukan dan lansia yang mengalami demensia. Hasilnya ditemukan ada 46 lansia yang memenuhi kriteria inklusi untuk dijadikan sampel. Penelitian ini menggunakan kuesioner untuk pengumpulan data. Variabel dalam penelitian ini adalah konsep diri pada lansia di Panti Werdha Pangesti Lawang dengan sub variabel gambaran diri, ideal diri, harga diri, peran dan identitas diri lansia yang tinggal di panti. Penelitian ini dilakukan pada tanggal 2425 Mei 2016.

Data yang terkumpul dimasukkan dalam tabulasi data yang dibuat peneliti, dari inisial responden kemudian diskor dan hasil yang ada

kemudian dijumlahkan ke skor maksimal dan dihitung sesuai prosentasenya. Data mengenai konsep diri pada lansia yang tinggal di panti diolah dengan cara skoring yaitu untuk pernyataan positif, skor= 1 untuk jawaban "ya", skor= 0 untuk jawaban "tidak". Untuk pernyataan negatif, skor $=0$ untuk jawaban "ya", skor= 1 untuk jawaban "tidak".

Di dalam melakukan penelitian, peneliti memperhatikan masalah etika penelitian yang meliputi: Informed consent, Anonimity, Confidentiality, Protection from Discomfort dan Beneficence

\section{HASIL DAN PEMBAHASAN}

\section{Karakteristik Responden}

Hasil penelitian menunjukkan bahwa usia responden yang paling banyak adalah >69-79 tahun yakni $(39,10 \%)$, lebih dari setengah responden $(67,4 \%)$ berjenis kelamin perempuan, pendidikan responden terbanyak adalah SD yakni 36,90\% dan lebih dari setengah responden $(65,20 \%)$ tinggal di panti selama 0-36 bulan.

\section{Gambaran Khusus}

\section{Gambaran diri Lansia yang Tinggal di Panti Werdha Pangesti Lawang}

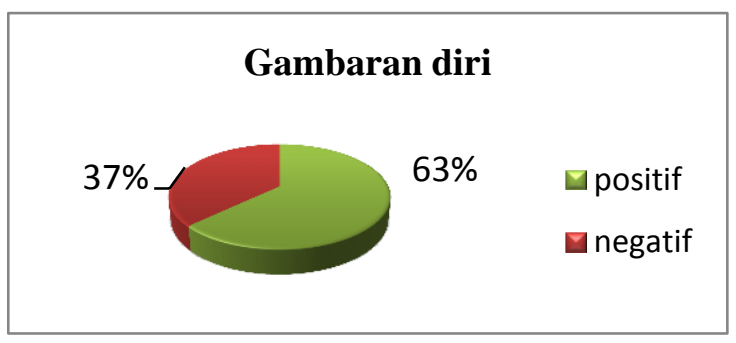

Gambar 1. Gambaran diri Lansia yang Tinggal di Panti Werdha Pangesti Lawang 
2. Ideal diri Lansia yang Tinggal di Panti Werdha Pangesti Lawang

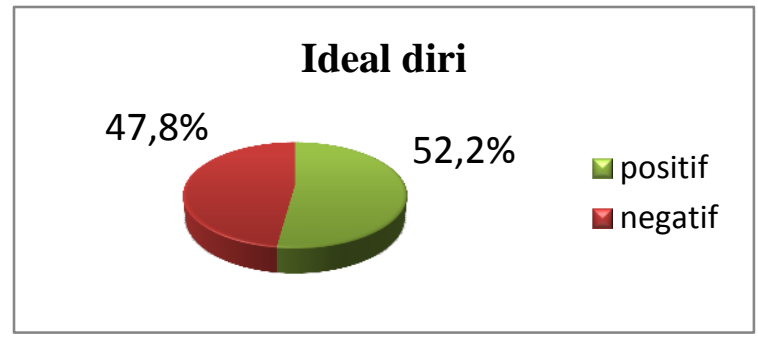

Gambar 2. Ideal diri Lansia yang Tinggal di Panti Werdha Pangesti Lawang

\section{Harga diri Lansia yang Tinggal di Panti} Werdha Pangesti Lawang

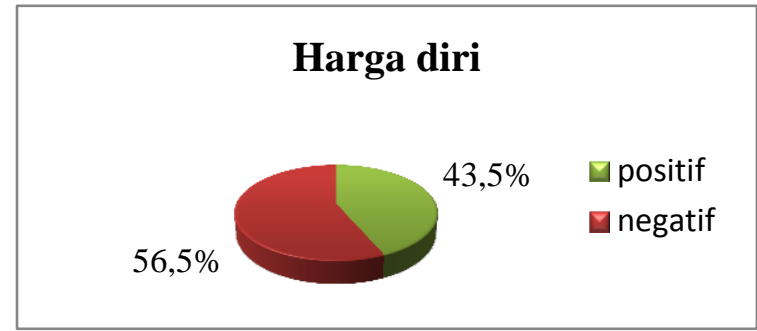

Gambar 3. Harga diri Lansia yang Tinggal di Panti Werdha Pangesti Lawang

\section{Penampilan peran Lansia yang Tinggal di} Panti Werdha Pangesti Lawang

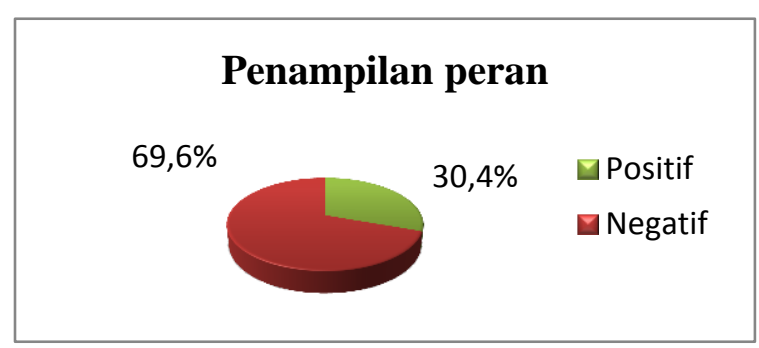

Gambar 4. Penampilan Peran Lansia yang Tinggal di Panti Werdha Pangesti Lawang

5. Identitas diri Lansia yang Tinggal di Panti Werdha Pangesti Lawang

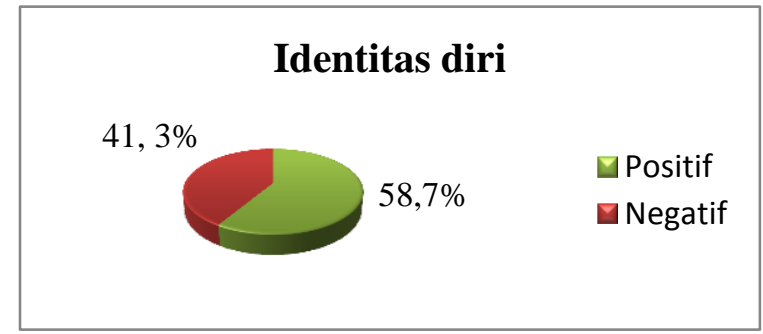

Gambar 5. Identitas diri Lansia yang Tinggal di Panti Werdha Pangesti Lawang
6. Konsep diri Lansia yang Tinggal di Panti Werdha Pangesti Lawang

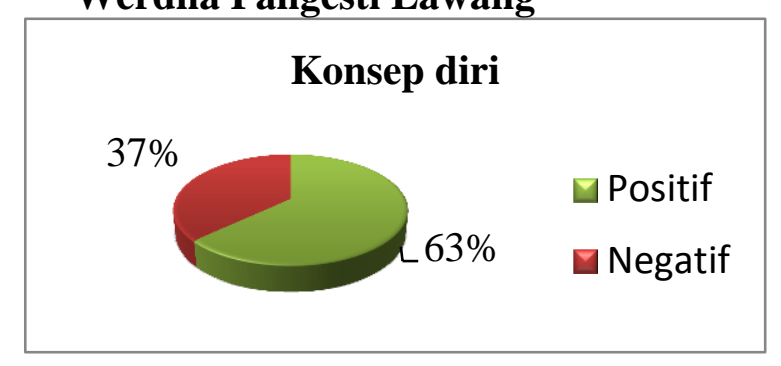

Gambar 5. Konsep diri Lansia yang Tinggal di Panti Werdha Pangesti Lawang

\section{PEMBAHASAN}

Gambaran Diri Lansia yang Tinggal di

\section{Panti Werdha Pangesti Lawang}

Hasil penelitian menunjukkan bahwa lebih dari setengah responden memiliki gambaran diri yang positif.

Gambaran diri adalah sikap individu terhadap tubuhnya baik disadari atau tidak disadari meliputi persepsi mengenai ukuran, bentuk, fungsi, penampilan, dan potensi tubuh (Suliswati, 2005). Gambaran diri seseorang dipengaruhi oleh jenis kelamin, usia, media massa, keluarga dan hubungan interpersonal.

Melihat dari aspek jenis kelamin, hasil penelitian ini menunjukkan bahwa lebih dari setengah responden berjenis kelamin wanita, namun hal ini tidak menunjukkan bahwa jenis kelamin wanita cenderung memiliki gambaran diri yang positif dibandingkan laki-laki sebab hasil penelitian juga menunjukkan bahwa sebagian besar $(73,3 \%)$ responden laki-laki juga memiliki gambaran diri yang positif.

Hasil ini sesuai dengan beberapa hasil penelitian sebelumnya yang menyatakan bahwa wanita lebih negatif memandang citra tubuh (body image) dibandingkan pria (Davidson\&McCabe, dalam Hubley\&Quinlan, 2005). Menurut Pudjidjogyanti (2008) wanita 
mempunyai konsep diri yang bersumber dari keadaan fisik dan popularitas dirinya sehingga wanita kurang mampu menyesuaikan diri dengan perubahan fisiknya berbeda dengan lansia laki-laki yang cenderung memiliki sifat tidak terlalu peduli dengan penampilan.

Menurut peneliti hal ini terjadi karena tinggalnya lansia bersama teman-teman yang seusia, sama-sama mengalami kemunduran fisik akan membuat lansia merasa diterima oleh kelompok sosialnya sehingga lansia menerima kenyataan diri dan kondisi hidup yang ada walaupun kenyataan tersebut di bawah kondisi yang diharapkan.

Dari aspek pendidikan, hasil penelitian menunjukkan bahwa pendidikan responden yang terbanyak adalah SD, namun hal ini tidak menunjukkan bahwa tingkat pendidikan yang lebih rendah cenderung membuat gambaran diri yang positif karena hasil penelitian juga menunjukkan bahwa lebih dari setengah responden $(63,6 \%)$ yang berpendidikan SMA juga memiliki gambaran diri yang positif.

Hal ini sesuai dengan pendapat Miller (2004) dalam (Zulfitri, 2011) yang menyatakan bahwa tingkat pendidikan yang lebih tinggi akan membuat seseorang memiliki tingkat kesadaran yang lebih tinggi akan datangnya masa tua dan membuat penerimaan diri yang lebih baik.

Ditinjau dari aspek umur, hasil penelitian menunjukkan bahwa responden terbanyak adalah umur >69-79 tahun dan lebih dari setengah responden berumur >69-79 tahun memiliki gambaran diri yang positif. Hal ini menunjukkan bahwa lansia dengan umur yang lebih muda akan memiliki gambaran diri yang positif dibandingkan dengan lansia yang berumur lebih tua.

Menurut Papalia \& Olds (2003) semakin bertambah umur lansia maka akan semakin berpengaruh pada penurunan fisik dan penampilan yang akan berpengaruh pada gambaran diri lansia. Menurut peneliti hal ini disebabkan karena semakin bertambahnya umur maka semakin banyak perubahan dan penurunan fungsi fisik sehingga akan mempengaruhi gambaran diri lansia ke arah yang negatif.

Dari aspek lamanya tinggal di panti, hasil penelitian menunjukkan bahwa lebih dari setengah responden tinggal di panti selama 0 36 bulan dan lebih dari setengah responden memiliki gambaran diri yang positif. Hal ini menunjukkan bahwa semakin pendek waktu tinggal lansia di panti akan semakin baik gambaran dirinya. Namun lama tinggal tidak semata-mata mempengaruhi gambaran diri karena ada $50 \%$ lansia yang tinggal di panti selama $>72-132$ bulan juga memiliki gambaran diri yang positif.

Menurut peneliti hal ini disebabkan karena berbedanya waktu yang dibutuhkan tiap lansia untuk beradaptasi dengan lingkungan baru.

\section{Ideal Diri Lansia yang Tinggal di Panti Werdha Pangesti Lawang}

Hasil penelitian menunjukkan bahwa lebih dari setengah responden memliki ideal diri yang positif. Ideal diri bisa diartikan 
dengan cita-cita, keinginan, harapan tentang diri sendiri.

Melihat dari aspek jenis kelamin, hasil penelitian ini menunjukkan bahwa lebih dari setengah responden berjenis kelamin wanita dan lebih dari setengah responden wanita memliki ideal diri yang positif. Hal ini menunjukkan bahwa lansia wanita cenderung memiliki ideal diri yang positif dibandingkan lansia laki-laki.

Menurut Darmojo (2004) dilihat dari domain psikologis, lansia wanita sifatnya cenderung sabar dan lebih bisa mengendalikan emosi dibandingkan laki-laki, hal inilah yang menyebabkan lansia perempuan bisa lebih berpikir, berharap dan bertingkah laku sesuai usianya yang telah lanjut dan sesuai kemampuan yang masih dimiliki.

Dari aspek umur, hasil penelitian menunjukkan bahwa $100 \%$ responden berumur lebih dari 60 tahun dan lebih dari setengah responden memliki ideal diri yang positif . Hal ini sesuai dengan pendapat Imron (2009) dalam (Zulfitri, 2011) yang menyebutkan bahwa pada usia 60 tahun ke atas, lansia mempunyai perasaan positif tentang kehidupan, salah satunya adalah dapat menemukan makna hidup yaitu bisa menerima keadaan yang ada tanpa harus menetapkan standar diluar kemampuannya.

Dari aspek pendidikan, hasil penelitian menunjukkan bahwa responden terbanyak adalah lulusan SD dan dan lebih dari setengahnya memliki ideal diri yang positif. Hal ini menunjukkan bahwa tingkat pendidikan yang rendah membuat lansia yang tinggal di panti cenderung memiliki ideal diri yang positif.

Hasil ini berbeda dengan pendapat Harlock (2002) yang menyatakan bahwa semakin tinggi pendidikan seseorang maka akan semakin puas dengan hidupnya. Menurut peneliti hal ini terjadi karena lansia dengan pendidikan yang lebih tinggi berpikir bahwa hidupnya tidak ideal untuk tinggal di panti. Mereka yang memiliki pendidikan lebih tinggi akan memiliki standart hidup yang lebih tinggi dan tinggal di panti bukanlah standart hidup mereka.

\section{Harga Diri Lansia yang Tinggal di Panti Werdha Pangesti Lawang}

Hasil penelitian menunjukkan bahwa lebih dari setengah responden memliki harga diri negatif.

Harga diri adalah penilaian individu tentang kesesuaian perilakunya dengan ideal diri yang diharapkan. Harga diri sesorang dipengaruhi oleh jenis kelamin, intelejensia, kondisi fisik, lingkungan keluarga, lingkungan sosial.

Melihat dari aspek jenis kelamin, hasil penelitian ini menunjukkan bahwa lebih dari setengah responden berjenis kelamin wanita, namun hal ini tidak menunjukkan bahwa jenis kelamin wanita cenderung memiliki harga diri yang negatif dibandingkan laki-laki sebab hasil penelitian juga menunjukkan bahwa sebagian besar $(81,8 \%)$ responden laki-laki memiliki harga diri yang negatif.

Hal ini sesuai dengan penelitian terbaru yang dilakukan oleh Longevity Centre 
International (ILC-UK) and the Charity, Independent Age,diketahui bahwa pria lebih mungkin untuk merasa kesepian di usia tua daripada wanita. Kesepian merupakan perasaan terasing (terisolasi atau kesepian) adalah perasaan tersisihkan, terpencil dari orang lain, karena merasa berbeda dengan orang lain (Probosuseno, 2007).

Dari aspek pendidikan, hasil penelitian menunjukkan bahwa responden paling banyak adalah lulusan SD namun hal ini tidak menunjukkan bahwa lulusan yang lebih rendah membuat harga diri menjadi negatif sebab hasil penelitian juga menunjukkan bahwa lebih dari setengah responden $(63,6 \%)$ berpendidikan SMA memiliki harga diri yang negatif.

Hasil ini berbeda dengan pendapat Miller (2004) dalam (Zulfitri, 2011) yang menyatakan bahwa tingkat pendidikan yang lebih tinggi akan membuat seseorang memiliki tingkat kesadaran yang lebih tinggi akan datangnya masa tua dan membuat penerimaan diri yang lebih baik. Menurut peneliti hal ini disebabkan karena lansia dengan pendidikan tinggi berpikir bahwa hidupnya tidak ideal untuk tinggal di panti.

Dari aspek lamanya tinggal di panti, hasil penelitian menunjukkan bahwa lebih dari setengah responden $(63,10 \%)$ tinggal di panti selama 0-36 bulan, namun hal ini tidak menunjukkan bahwa lebih pendeknya masa tinggal lansia di panti cenderung membuat harga diri menjadi negatif sebab ada $50 \%$ lansia yang tinggal di panti selama >72-132 bulan juga memiliki harga diri yang negatif.
Hal ini sesuai dengan penelitian yang dilakukan oleh Maniung, Inri, dkk (2015) tentang "Hubungan Lama Tinggal dengan Tingkat Depresi pada Lansia di Panti Tresna Werdha Agape Tandano" hasil penelitian menunjukkan bahwa tidak ada hubungan antara lama tinggal dengan tingkat depresi lansia. Salah satu ciri-ciri dari depresi adalah harga diri yang rendah. Menurut peneliti hal ini terjadi karena faktor lain seperti jenis kelamin dan tingkat pendidikan.

Ditinjau dari aspek umur, hasil penelitian menunjukkan bahwa responden terbanyak adalah umur >69-79 namun usia yang lebih muda tidak semata-mata menjadikan harga diri negatif sebab hasil penelitian juga menunjukkan bahwa lebih dari setengah responden $(58,3 \%)$ dengan usia 80-89 tahun juga memiliki harga diri yang negatif.

Menurut peneliti hal ini terjadi karena tidak semua lansia pasti menunjukkan tingkat kemunduran yang sama dalam umur yang sama. Harga diri lansia yang tinggal di panti juga dipengaruhi oleh minimnya kegiatan di panti. Semua pekerjaan di panti dikerjakan tanpa melibatkan lansia sehingga lansia merasa tidak dipercaya untuk mandiri dan mengambil keputusan sendiri. Menurut Darmojo (2000) kegiatan-kegiatan dan hobi memungkinkan usia lanjut masih merasa bermanfaat bagi orang lain.

\section{Peran Lansia yang Tinggal di Panti Werdha Pangesti Lawang}


Santi Susilawati, Agus Setyo U, Nurul Hidayah, Konsep Diri pada Lansia...

Hasil penelitian diatas menunjukkan bahwa sebagian besar responden memiliki penampilan peran yang negatif.

Peran adalah serangkaian pola perilaku, nilai dan tujuan yang diharapkan oleh masyarakat sesuai dengan fungsi individu di dalam kelompok sosialnya.Penampilan peran dipengaruhi oleh perubahan peran.

Melihat dari aspek jenis kelamin, hasil penelitian ini menunjukkan bahwa lebih dari setengah responden berjenis kelamin perempuan, namun hal ini tidak menunjukkan bahwa jenis kelamin wanita cenderung memiliki penampilan peran yang negatif dibandingkan laki-laki sebab hasil penelitian menunjukkan bahwa $100 \%$ lansia yang berjenis kelamin laki-laki juga memiliki penampilan peran yang negatif sedangkan pada lansia wanita hanya $54,8 \%$ yang memiliki penampilan peran negatif.

Menurut Harlock (2002) lansia laki-laki lebih cenderung membatasi minat pada kegiatan berbeda dengan lansia wanita yang cenderung untuk berusaha terlibat dalam kegiatan yang bervariasi luas selama hidupnya. Menurut peneliti penampilan peran yang negatif dari lansia disebabkan oleh minimnya kegiatan yang bisa dilakukan oleh lansia di panti dan tinggal di panti juga membuat rutinitas, hobi yang biasanya dilakukan di rumah menjadi terhenti.

Ditinjau dari aspek umur, hasil penelitian menunjukkan bahwa responden terbanyak adalah umur >69-79 tahun namun usia yang lebih muda tidak semata-mata membuat penampilan peran sebagian besar responden negatif sebab hasil penelitian juga menunjukkan bahwa sebagian besar $(83,3 \%)$ responden dengan usia >79-89 memiliki penampilan diri negatif.

Hasil ini sesuai dengan teori social disengagement yang menyebutkan semakin bertambahnya umur maka kegiatan sosialpun semakin berkurang karena semakin bertambahnya umur maka semakin sulit lansia dalam beradaptasi dan berinteraksi dengan lingkungan.

Dari aspek pendidikan hasil penelitian menunjukkan bahwa lulusan terbanyak responden adalah lulusan SD dan sebagian besar responden lulusan SD memiliki penampilan peran yang negatif. Hal ini menunjukkan bahwa semakin rendah pendidikan lansia maka semakin negatif penampilan perannya, hal ini sesuai dengan pendapat Harlock (2002) semakin tinggi dan dan semakin formal tingkat pendidikan yang dimiliki seseorang semakin banyak pula kegiatan yang dimiliki untuk menciptakan penampilan peran yang positif.

Dari aspek lamanya tinggal di panti, hasil penelitian menunjukkan bahwa lebih dari setengah responden tinggal di panti selama 036 bulan dan sebagian besar responden memiliki penampilan peran yang negatif. Hal ini menunjukkan bahwa semakin pendek waktu tinggal lansia di panti akan semakin negatif penampilan perannya dan semakin lama waktu tinggal lansia di panti semakin baik penampilan perannya .

Hal ini sesuai dengan pendapat Hurlock (2002) semakin terbiasa baik pria maupun 
wanita hidup bersama dengan orang lain dan mengambil kegiatan bersama, maka mereka akan semakin dapat menikmati kontak sosial maupun kegiatan yang diadakan oleh lembaga.

\section{Identitas Diri Lansia yang Tinggal di Panti Werdha Pangesti Lawang}

Hasil penelitian menunjukkan bahwa lebih dari setengah responden memiliki identitas diri yang positif. Identitas diri adalah penilaian individu tentang dirinya sendiri yang berbeda dengan orang lain. Identitas diri dipengaruhi oleh perubahan peran, orang tua, teman sebaya.

Hasil penelitian menunjukkan bahwa $51,9 \%$ lansia dengan identitas diri positif memiliki peran diri yang positif, dan $100 \%$ lansia dengan identitas diri negatif juga memiliki peran yang negatif. Hal ini menunjukkan identitas diri lansia dipengaruhi oleh penampilan peran lansia.

Menurut peneliti identitas diri lansia yang positif disebabkan karena Mereka menerima ketidaksempurnaan pada dirinya dan hidupnya seperti halnya menerima akan dekatnya dengan kematian. Mereka memperoleh arti hidup pada masa lalu, kini dan yang akan datang. Sedangkan identitas negatif disebabkan oleh perlakuan orang lain yang memperlakukan mereka seperti anak-anak dan atau seperti orang dewasa dan perubahan peran yang dialami oleh lansia.

Menurut Erik Erikson dalam Suadirman (2011) orang tua jauh lebih arif daripada orang muda, mereka lebih arif dalam menyikapi keadaannya yang berbeda dengan orang lain.
Menurut Erickson dalam (Hurlock, 2002) pada lansia akan mengalami krisis identitas yang terjadi ketika keharusan lansia untuk melakukan perubahan peran yang drastis dari pekerja yang sibuk penuh optimis menjadi penganggur yang tidak menentu.

\section{Konsep diri Lansia yang Tinggal di Panti Werdha Pangesti Lawang}

Hasil penelitian diatas menunjukkan bahwa lebih dari setengah responden memiliki konsep diri yang positif.

Menurut peneliti hal tersebut dikarenakan lebih dari setengah responden memiliki gambaran diri yang positif. Gambaran diri yang positif ini akan membuat konsep diri lansia menjadi positif. Menurut Stuart dan Laraia (2001) seiring dengan pertambahan usia dan proses penuaan, lansia mengalami perubahan bentuk tubuh, penurunan fungsi tubuh serta penyakit kronis. Hal tersebut dapat menjadi faktor yang mempengaruhi konsep diri lansia. Namun umumnya lansia akan melakukan penyesuaian agar dapat siap menerima masa usia lanjutnya. Sehingga konsep dirinya menjadi positif

Menurut peneliti faktor lain yang membuat konsep diri lansia menjadi positif adalah tinggalnya lansia di panti akan memberikan kesemapatan besar bagi lansia untuk berhubungan dengan teman seusia yang mempunyai minat dan kemampuan yang sama sehingga membuat lansia merasa diterima di lingkungannya termasuk diterima oleh perawatperawat di panti. 
Menurut Setyaningsih (2011) konsep diri tidak lepas dari proses pembelajaran, motivasi dan dukungan dari orang lain. Semakin besar motivasi yang baik dari orang lain akan semakin baik pula penilaian individu terhadap dirinya sendiri.

\section{KESIMPULAN}

Hasil penelitian menunjukkan bahwa lebih dari setengah responden memiliki gambaran diri yang positif, lebih dari setengah responden memiliki ideal diri yang positif, lebih dari setengah responden memliki harga diri negatif, sebagian besar responden memiliki penampilan peran yang negatif, lebih dari setengah responden memiliki identitas diri yang positif, lebih dari setengah responden memiliki konsep diri yang positif.

\section{DAFTAR RUJUKAN}

Andini \& Supriyadi. 2013. Hubungan antara Berpikir Positif dengan Harga Diri pada Lansia yang Tinggal di Panti Jompo di Bali. Jurnal Psikologi Universitas Udayana, 1 (1): 129-137

\section{Azizah, L. M. 2011. Keperawatan Lanjut Usia. Yogyakarta: Graha Ilmu}

Darmojo \& Martono. 2000. Geriatri (Ilmu Kesehatan Usia Lanjut). Jakarta: Balai Penerbit Universitas Indonesia

Darmojo, 2004. Geriatri (Ilmu Kesehatan Usia Lanjut). Jakarta: Balai Penerbit Universitas Indonesia

Hurlock, Elizabeth B. 2002. Psikologi Perkembangan.Jakarta: Erlangga
Kelliat, B.A. 1992. Gangguan Konsep Diri. Jakarta: EGC

Mass, L. Meridean, et al. 2011. Asuhan Keperawatan Geriatrik. Jakarta: EGC

Nugroho, Wahjudi. 2008. Keperawatan Gerontik dan Geriatrik. Jakarta: EGC

Setyowati, Erni. 2012. Analisa Konsep Diri Pada Lanjut Usia yang dirawat di Panti Werdha Darma Bakti Surakarta. Tesis. Surakarta: Universitas Muhammadiyah Surakarta

Siregar, dkk. 2013. Perbandingan Kualitas Hidup Lanjut Usia yang Tinggal di Panti Jompo dengan yang Tinggal di Rumah di Kabupaten Tapanuli Selatan. Skripsi. Universitas Sumatera Utara

Stuart \& Laraia. (2001). Buku Saku

Keperawatan Jiwa, Edisi 5. Jakarta: EGC

Suardiman, S. 2011. Psikologi usia lanjut. Yogyakarta: Gadjah Mada University Press

Suliswati, dkk. 2005. Konsep Dasar Kesehatan Jiwa. Jakarta:EGC

Zulfitri, Reni, 2011. Konsep Diri dan Gaya Hidup Lansia yang Mengalami Penyakit Kronis di Panti Sosial Tresna Werdha (PSTW) Khusnul Khotimah Pekanbaru. Jurnal Ners Indonesia, 1 (2): 21-30 